\title{
Knowledge and Attitude Toward Human Papillomavirus and HPV Vaccination in Iranian Population: A Systematic Review
}

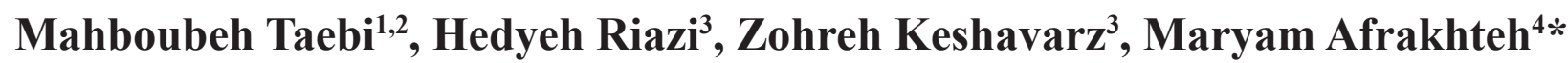

\begin{abstract}
Background and objective: Human papillomavirus (HPV) is the main cause of cervical cancer. This systematic review was performed to provide an overview of knowledge and attitude about HPV infection and HPV vaccine in Iranian population. Materials and Methods: The information was identified by searching international and national databases; pubmed/MEDLINE (NCBI), Embase (Elsevier), Google Scholar, Scientific Information Database, MagIran, and IranDoc. The current research was performed using the terms of medical subject headings (MeSH) and combinations of the keywords including: "human papillomavirus" or "human papillomavirus vaccine" with the words "knowledge," "awareness," "attitude" and "Iran." Studies were evaluated according to the checklist of STrengthening the Reporting of OBservational Studies in Epidemiology (STROBE). Results: A total of 10 observational studies that met the inclusion criteria were included in this review. The overall knowledge and awareness of the Iranian population (parents, women, university students, medical students, nurses and hospital staff) about HPV and HPV vaccination was low; however, the attitude toward this issue was positive and strong. Conclusion: Due to the low levels of knowledge about HPV infection and its methods of prevention, efforts should be increased to enhance the knowledge of the general population about HPV infection and vaccination in order to prevent its incidence and complications.
\end{abstract}

Keywords: Sexually transmitted infections- human papillomavirus- HPV- attitude- Knowledge

Asian Pac J Cancer Prev, 20 (7), 1945-1949

\section{Introduction}

Human papillomavirus (HPV) is one of the most common sexually transmitted infections (STIs), and approximately 5.5 million people develop genital HPV infections annually (Baseman and Koutsky, 2005; Dunne et al., 2007). The role of HPV in cervical cancer is well known. Almost all cases of cervical pre-invasive neoplasia and invasive squamous cell cervical cancers are associated with HPV infection (Slomovitz et al., 2006). HPV infection occurs in women of all age groups, and the highest rate of HPV infection is seen in women of 20-24 years old (Dunne et al., 2007). It was estimated that 630,000 new HPV-related cancers was occurred in women in 2012, of which 530,000 (84\%) were cervical cancer (Martel et al., 2017). The global prevalence of HPV among women with normal cytological findings is estimated to be 11.7\% (95\% confidence interval CI: 11.6-11.7\%) (Bruni et al., 2010). However, country-specific adjusted HPV prevalence in cervical specimens ranged from $1.6 \%$ to 41.9\% worldwide (Smith et al., 2008), and its prevalence in Iranian population was estimated as 9.4\% (95\% confidence interval [CI]: 6.8-12.02 (Malary et al., 2016).
HPV viruses would spread through contact with infected genital skin, mucous membranes, or bodily fluids, and could be transmitted through sexual intercourse. Human Papillomavirus genotypes are classified as high risk and low risk according to their potential to cause cancer. The most common low risk types are HPV 6 and 11 that cause benign warts. High risk HPV are associated with development of cervical carcinoma (types 16,18, 31, 33, 45, 52, and 58) (Smith et al., 2008; Jalilian et al., 2017).

Although there is no virus-specific treatment for HPV infection, screening and treatment for pre-invasive disease of the cervix is highly successful in preventing progression to cervical cancer (Jalilian et al., 2017). Three prophylactic HPV vaccines, directed against high-risk HPV types, are available and marketed in many countries for preventing HPV infection. Quadrivalent vaccine (Gardasil: targets HPV types 6, 11, 16, and 18) was first licensed in 2006, Bivalent vaccine (Cervarix: targets HPV types 16 and 18) in 2007 and 9-valent vaccine (Gardasil 9: targets HPV types 6, 11, 16, 18, 31, 33, 45, 52, and 58.) in 2014. All of these vaccines are intended to be administered, if possible, before the onset of sexual activity (WHO, 2017; Cox and Palefsky, 2018). Current evidence suggests

${ }^{1}$ Student Research Committee, ${ }^{3}$ Department of Midwifery and Reproductive Health,School of Nursing and Midwifery, ${ }^{4}$ Department of Obstetrics and Gynecology, School of Medicine, Shahid Beheshti University of Medical Sciences, Tehran, ${ }^{2}$ Department of Midwifery and Reproductive Health, School of Nursing and Midwifery, Isfahan University of Medical Sciences, Isfahan, Iran. *For Correspondence:m_afrakhteh1@yahoo.com 
that the 3 licensed HPV vaccines have relatively similar effectiveness in preventing cervical cancer (Naud et al., 2014). WHO position paper (2017) on HPV vaccines recommended that all the countries should proceed with nationwide introduction of HPV vaccination.

For better management and treatment of HPV, it is necessary to get an overview of knowledge and attitude toward HPV infection in general population. Several studies have indicated that despite the high prevalence of HPV, even among informed people, there is lack of knowledge or false perceptions towards HPV. Despite HPV consequences, most women are not aware of it and had never heard of the HPV (Blodt et al., 2012; Marlow et al., 2012; pourkazemi et al., 2016); and men and women have a weak awareness about the HPV's relation with cervical cancer before and after vaccination (Medeiros et al., 2010; Fakor et al., 2016; Nekooi et al., 2016). There is evidence that acceptance of HPV vaccination is increased when parents or young women are well informed about its risks and benefits (Kahn et al., 2003; Klug et al., 2008). So, knowledge and attitude toward HPV infection and HPV vaccines will greatly influence the success of an immunization program against cervical cancer (Klug et al., 2008). Therefore, we performed a systematic review on various literature databases to determine the knowledge and attitude about HPV and HPV vaccine in Iranian population.

\section{Materials and Methods}

The present study reviewed the studies that have evaluated knowledge, awareness, and attitude toward HPV and HPV vaccines in Iran, by searching international databases of PubMed/MEDLINE (NCBI), Embase (Elsevier), Google Scholar and Iranian databases of Scientific Information Database, Magiran and IranDoc from their earliest dates until December 07, 2017. Bibliographies of relevant reviews and eligible studies were examined for additional sources. The current research was performed using the terms of medical subject headings (MeSH) and combinations of the keywords including: "human papillomavirus" or "human papillomavirus vaccination" with the words "knowledge," "awareness," "attitude" and "Iran." The search was conducted without language restriction. Titles and abstracts of the selected articles were reviewed by two authors and categorized as relevant using the criteria. Observational studies were considered for inclusion if they were published for Iranian population and examined the knowledge or attitude about human papillomavirus or human papillomavirus vaccination. Two reviewers evaluated the articles according to the checklist of STrengthening the Reporting of OBservational Studies in Epidemiology (STROBE), and their disagreements were delivered to a third party. After precise extraction of the required data, extracted results were summarized in a table that was composed of authors, publication year, the population of the study, the sample size, method, and level of knowledge and attitude toward HPV and HPV vaccination. Finally, after eliminating articles with weak relation to the objectives of the study, 10 fully related articles were included to the study and were completely studied and investigated (Figure 1).

\section{Results}

Overall, 617 articles dealing human papillomavirus or human papillomavirus vaccination were identified, of which 583 were excluded due to their titles, abstract, inaccessibility of full text and not-relevant subjects. A total of 10 articles that met the inclusion criteria were included in this systematic review (Table 1). All of the studies were observational and conducted in Iran. In total, 3,501 participants were surveyed. In this review, the knowledge and attitude of the Iranian population (parents, women, university students, medical students, nurses and hospital staff) about HPV and HPV vaccination were evaluated.

\section{Knowledge and attitude toward HPV infection}

Knowledge about HPV infection varied widely within the groups according to the questions that were asked in the studies; but the overall knowledge and awareness about this STI were low. In a study that was conducted on university students and hospital staff, $20.1 \%$ did not

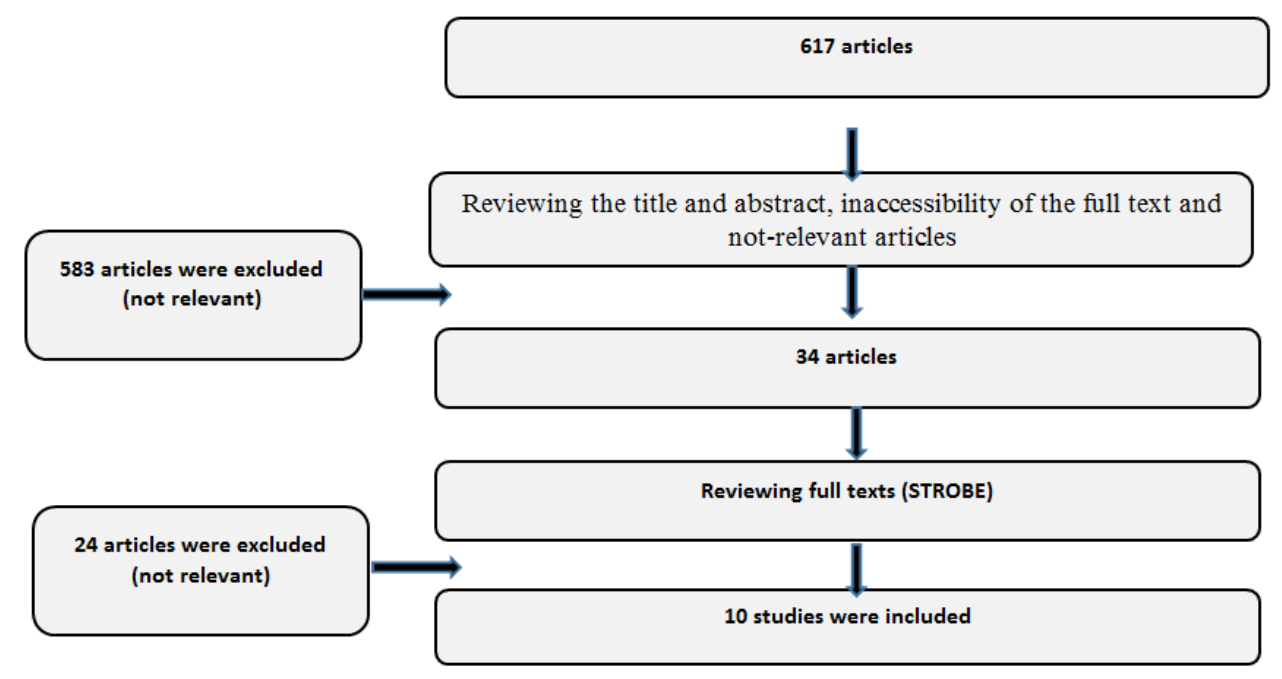

Figure 1. The Flowchart for Article Selection 
DOI:10.31557/APJCP.2019.20.7.1945

Knowledge and Attitude Toward Human Papillomavirus and HPV Vaccination in Iranian Population

Table 1. Overview of Knowledge and Attitude Toward Human Papillomavirus and HPV Vaccination in Iranian Population

\begin{tabular}{|c|c|c|c|c|c|}
\hline Author/year & Demographic & $\begin{array}{c}\text { Sample Size/ } \\
\text { Method/ Subject }\end{array}$ & Level of knowledge & Level of attitude & Final result \\
\hline $\begin{array}{l}\text { Pourkazemi } \\
\text { et al., } 2016\end{array}$ & $\begin{array}{l}\text { Medical students } \\
\text { (female and male) }\end{array}$ & $\begin{array}{l}\text { 201; Survey: } \\
\text { cross-sectional/ } \\
\text { HPV }\end{array}$ & $\begin{array}{c}\text { Desirable: } 42.8 \% \\
\text { Undesirable: } 57.2 \% \\
\text { Mean score: } 18.9 \pm 4.37\end{array}$ & $\begin{array}{l}\text { Desirable: } 57.2 \% \\
\text { Undesirable: } 42.8 \% \\
\text { Mean score: } \\
23.57 \pm 3.29\end{array}$ & $\begin{array}{c}\text { Low awareness of HPV; but attitude } \\
\text { to HPV was desirable. }\end{array}$ \\
\hline $\begin{array}{l}\text { Fakor } \\
\text { et al., } 2016\end{array}$ & $\begin{array}{l}\text { Medical students } \\
\text { (female and male) }\end{array}$ & $\begin{array}{l}\text { 90; Survey: cross- } \\
\text { sectional/ HPV } \\
\text { vaccine }\end{array}$ & $\begin{array}{l}\text { Mean score: } 5.17 \pm 3.24 \\
\text { (answers ranging from } 5 \\
\text { to } 13 \text { ) }\end{array}$ & $\begin{array}{l}\text { Mean score: } 52.16 \\
\pm 5.04 \text { (answers } \\
\text { ranging from } 38 \\
\text { to } 63 \text { ) }\end{array}$ & $\begin{array}{l}\text { Level of knowledge and attitude } \\
\text { about HPV vaccination was low. }\end{array}$ \\
\hline $\begin{array}{l}\text { Malakouti } \\
\text { et al., } 2016\end{array}$ & $\begin{array}{l}\text { Women }(15-49 \\
\text { years old) }\end{array}$ & $\begin{array}{l}\text { 221; Survey: } \\
\text { cross-sectional/ } \\
\text { HPV }\end{array}$ & $\begin{array}{l}\text { Mean score: } 12.04 \pm 3.9 \\
\text { (answers ranging from } 0 \\
\text { to } 20 \text { ) }\end{array}$ & Not discussed & $\begin{array}{l}\text { Low knowledge of HPV. No } \\
\text { significant differences was seen } \\
\text { between knowledge about HPV in } \\
\text { participants with and without HPV }\end{array}$ \\
\hline $\begin{array}{l}\text { Nekooi } \\
\text { et al., } 2016\end{array}$ & $\begin{array}{l}\text { Women }(15-49 \\
\text { years old })\end{array}$ & $\begin{array}{l}\text { 200; Survey: } \\
\text { cross-sectional/ } \\
\text { HPV }\end{array}$ & $\begin{array}{l}\text { Weak: } 76 \% \\
\text { Moderate: } 13 \% \\
\text { Strong: } 11 \%\end{array}$ & Not discussed & $\begin{array}{l}\text { The level of knowledge about } \\
\text { HPV, genital warts, and methods } \\
\text { of infection transmission and its } \\
\text { preventions was insufficient. }\end{array}$ \\
\hline $\begin{array}{l}\text { Asgarlou } \\
\text { et al., } 2016\end{array}$ & $\begin{array}{l}\text { University } \\
\text { students and } \\
\text { hospital staff } \\
\text { (female) }\end{array}$ & $\begin{array}{l}680 \text {; Survey: } \\
\text { cross-sectional/ } \\
\text { cervical cancer }\end{array}$ & $\begin{array}{l}20.1 \% \text { did not know the } \\
\text { routes of HPV transmission. } \\
\text { Only } 9.7 \% \text { of the samples } \\
\text { declared PCR as a diagnostic } \\
\text { method for papillomavirus. }\end{array}$ & Not discussed & $\begin{array}{l}\text { Low knowledge of HPV and its } \\
\text { transmission. }\end{array}$ \\
\hline $\begin{array}{l}\text { Salehifar and } \\
\text { Akbari, } 2015\end{array}$ & $\begin{array}{c}\text { University } \\
\text { students (female) }\end{array}$ & $\begin{array}{l}\text { 202; Survey: } \\
\text { cross-sectional/ } \\
\text { HPV vaccine }\end{array}$ & $\begin{array}{l}\text { Poor: } 17 \% \\
\text { Weak: } 66.8 \% \\
\text { Good: } 5 \% \\
\text { Mean score: - }\end{array}$ & $\begin{array}{l}\text { Positive: } 25.2 \% \\
\text { Negative: } 2.5 \% \\
\text { No comment: } \\
72.3 \% \\
\text { Mean score: } \\
24.5 \pm 3.2\end{array}$ & $\begin{array}{c}70 \% \text { of the students were willing } \\
\text { to receive the vaccine if it was } \\
\text { available. }\end{array}$ \\
\hline $\begin{array}{l}\text { Mojahed } \\
\text { et al., } 2013\end{array}$ & Female nurses & $\begin{array}{l}\text { 380; Survey: } \\
\text { cross-sectional/ } \\
\text { HPV and HPV } \\
\text { vaccine }\end{array}$ & $\begin{array}{l}\text { Only } 36.7 \% \text { of the nurses } \\
\text { knew about HPV infection }\end{array}$ & Not discussed & $\begin{array}{c}\text { Lack of knowledge about HPV } \\
\text { vaccine and its relation to cervical } \\
\text { cancer and the methods for } \\
\text { preventing this type of cancer. } 41.2 \% \\
\text { of the participants wanted to be } \\
\text { vaccinated. }\end{array}$ \\
\hline $\begin{array}{l}\text { Ghojazadeh } \\
\text { et al., } 2012\end{array}$ & $\begin{array}{l}\text { University } \\
\text { students (female } \\
\text { and male) }\end{array}$ & $\begin{array}{l}\text { 669; Survey: } \\
\text { cross-sectional/ } \\
\text { HPV }\end{array}$ & $\begin{array}{l}78.6 \% \text { of the participants } \\
\text { knew that HPV is a potential } \\
\text { cause for genital warts. But } \\
\text { general knowledge about the } \\
\text { details was not high. }\end{array}$ & Not discussed & $\begin{array}{l}\text { Post graduate midwifery and medical } \\
\text { students had a higher level of } \\
\text { knowledge about HPV transmission } \\
\text { routes comparing to the other groups. }\end{array}$ \\
\hline $\begin{array}{l}\text { Ghojazadeh } \\
\text { et al., } 2012\end{array}$ & Parents & $\begin{array}{l}\text { 358; Survey: } \\
\text { cross-sectional } \\
\text { multi center/ HPV }\end{array}$ & $\begin{array}{l}76 \% \text { of the parents had no } \\
\text { information about HPV } \\
\text { infection }\end{array}$ & Not discussed & $\begin{array}{l}\text { The average score of the mothers' } \\
\text { information about HPV infection was } \\
\text { higher than the fathers. Educational } \\
\text { level and age had significant impact } \\
\text { on the knowledge of parents about } \\
\text { HPV. Parents' knowledge about the } \\
\text { hazards of HPV was higher than their } \\
\text { knowledge about the methods of } \\
\text { transmission }\end{array}$ \\
\hline $\begin{array}{l}\text { Farzaneh } \\
\text { et al., } 2011\end{array}$ & $\begin{array}{l}\text { Women }(20-50 \\
\text { years old })\end{array}$ & $\begin{array}{l}\text { 500; Survey: } \\
\text { cross-sectional/ } \\
\text { HPV }\end{array}$ & & & $\begin{array}{l}\text { Knowledge of HPV (its relation } \\
\text { to cervical cancer and prevention } \\
\text { methods) was not enough. Attitude } \\
\text { towards education was extremely } \\
\text { positive. }\end{array}$ \\
\hline
\end{tabular}

know "the routes of HPV transmission." And 34.5\% of the participants had knowledge about "HPV leading to cervical cancer" (Asgarlou et al., 2016). Nekooi et al., (2016) showed that only $38.5 \%$ of the women had heard of HPV, while the knowledge level of $76 \%$ of the participants was assessed as weak. In the study of Ghojazadeh et al., (2012) $76 \%$ of the parents had no information about HPV infection. A study on university students showed that most of the respondents did not know that HPV is a common infection, but Pourkazemi et al., (2016) showed that, despite the low awareness about HPV, the attitude of more than half of the medical students was desirable.
Knowledge and attitude toward HPV vaccine

Results of a study on women, medical students and nurses showed that knowledge about the vaccination of HPV was low (Farzaneh et al., 2011; Mojahed et al., 2013; Salehifar and Akbari, 2015; Fakor et al., 2016). Most of the women (Farzaneh et al., 2011) and female nurses were unaware that immunization against HPV could prevent cervical cancer. Only $4.5 \%$ of the female nurses knew that vaccination of HPV could prevent cervical cancer (Mojahed et al., 2013). Salehifar and Akbari (2015) showed that $66.8 \%$ of the students had poor knowledge about the HPV vaccine and about 25 percent of them had a positive attitude toward HPV vaccination. Over $70 \%$ of the 
students reported that if the vaccine is available, they will be willing to receive it. Although knowledge about HPV, its relation to cervical cancer and its prevention methods is not enough, attitude towards education in this regard is extremely positive and most of the participants stated that they would receive the vaccine if it was available (Farzaneh et al., 2011; Salehifar and Akbari, 2015).

\section{Discussion}

The findings revealed that the level of knowledge about HPV infection and vaccination in Iranian population is concerning. The knowledge was poor; however, the attitude toward HPV infection and its vaccination was positive and strong. Our population is not aware of the transmission methods of this STI and its important consequences like cervical cancer. In Iran, 25.61 million women aged 15 years old and older are at the risk of cervical cancer, due to lack of knowledge about HPV infection (Malakouti et al., 2017). The total prevalence of HPV in Iran was 9.4\% (95\% confidence interval [CI]: 6.8-12.02) (Malary et al., 2016); and the epidemiology of the virus is fundamental to its prevention. As it is known, the success of any immunization program is closely related to the baseline knowledge and beliefs about the disease. Numerous studies have reported that most women are unaware of HPV and its association with cervical cancer. Unfortunately, awareness about HPV has not improved in the recent years (Dursun et al., 2009).

Right now, 71 countries (37\%) had introduced HPV vaccine in their national immunization program for girls (WHO, 2017). Australia was the first country that used HPV vaccine in their health system for the prevention of this infection (Brotherton et al., 2010). Gardasil is available to prevent HPV infection, but it is currently not included in the national vaccination program in Iran, and many people don't know about its advantages and its availability (Malakouti et al., 2017). Cost of the vaccine was reported as an important barrier to HPV vaccination programs (Dursun et al., 2009). Health policy in vaccination programs helps to address all HPV vaccine facilities. Coverage of immunization by the Iranian health system (Ministry of Health and Medical Education) could be an important cause for widely notifying the population of HPV and its vaccine. Health authorities should provide the vaccine information and educational program based on the individual factors, age, education and background of the patients to upgrade the knowledge of people about this virus infection and its prevention.

In conclusion, due to the low level of knowledge about HPV infection and its prevention methods, health authorities should implement some interventions to enhance the knowledge and attitude of the population about HPV infection and vaccination to prevent its incidence and complications. The results reflect the need for advertising and educational programs for the general population about HPV prevention methods, to reduce the prevalence of this infection.

\section{Acknowledgments}

The authors are thankful to all the researchers that their results were used for the present study, and also the vice chancellor in research affair of the Shahid Beheshti Medical Sciences University (SBMU) for providing access to the library and electronic database.

\section{References}

Asgarlou Z, Tehrani S, Asghari E, et al (2016). Cervical cancer prevention knowledge and attitudes among female university students and hospital staff in Iran. Asian Pac J Cancer Prev, 17, 4921-7.

Baseman JG, Koutsky LA (2005). The epidemiology of human papillomavirus infections. J Clin Virol, 32, 16-24.

Blodt S, Holmberg C, Muller-Nordhorn J, Rieckmann N (2012). Human Papillomavirus awareness, knowledge and vaccine acceptance: a survey among 18-25-year-old male and female vocational school students in Berlin, Germany. Eur J Public Health, 22, 808-13.

Brotherton JM, Kaldor JM, Garland SM (2010). Monitoring the control of human papillomavirus (HPV) infection and related diseases in Australia: towards a national HPV surveillance strategy. Sex Health, 7, 310-9.

Bruni L, Diaz M, Castellsague X, et al (2010). Cervical human papillomavirus prevalence in 5 continents: meta-analysis of 1 million women with normal cytological findings. J Infect Dis, 202, 1789-99.

Cox JT, Palefsky JM (2018). Human papillomavirus vaccination. avalable.at: https://www.uptodate.com/contents/humanpapillomavirus-vaccination. accessed may 2018.

Dunne EF, Unger ER, Sternberg M, et al (2007). Prevalence of HPV infection among females in the United States. JAMA, 297, 813-9.

Dursun P, Altuntas B, Kuscu E, Ayhan A (2009). Women's knowledge about human papillomavirus and their acceptance of HPV vaccine. Aust N Z J Obstet Gynaecol, 49, 202-6.

Fakor F, Ghanbari khanghah A, Mahfouzi L, Dalil Heirati SF, Graili S (2016). Knowledge and attitudes of medical students about human papilloma virus (HPV) vaccination and associated factors. J Holist Nurs Midwifery, 26, 71-9.

Farzaneh F, Shirvani HE, Barouti E, et al (2011). Knowledge and attitude of women regarding the human papillomavirus (HPV) infection, its relationship to cervical cancer and prevention methods. Med J Malaysia, 66, 468-73.

Ghojazadeh M, Azar ZF, Saleh P, Naghavi-Behzad M, Azar NG (2012). Knowledge and attitude of Iranian University students toward human papilloma virus. Asian Pac J Cancer Prev, 13, 6115-9.

Ghojazadeh M, Naghavi-Behzad M, Azar ZF, et al (2012). Parental knowledge and attitudes about human papilloma virus in Iran. Asian Pac J Cancer Prev, 13, 6169-73.

Jalilian S, Izadi B, Madani S H, Mohajeri P(2017). The prevalence and genotype distribution of human papillomavirus types in the general female population in west of Iran. Jundishapur $J$ Microbiol, 10, e40855.

Kahn JA, Rosenthal SL, Hamann T, Bernstein DI (2003). Attitudes about human papillomavirus vaccine in young women. Int J STD AIDS, 14, 300-6.

Klug SJ, Hukelmann M, Blettner M (2008). Knowledge about infection with human papillomavirus: a systematic review. Prev Med, 46, 87-98.

Malakouti J, Gorbani M, Salehi Poormehr H, Jafari Shabiri M, Pourasad Shahrak Sh (2017). Knowledge of human 
papillomavirus and its incidence among women referring to Al-Zahra and Taleghani Hospitals in Tabriz-Iran, 2014-2015. Int $J$ Womens Health Reprod Sci, 5, 143-6.

Malary M, Moosazadeh M, Hamzehgardeshi Z, et al (2016). The prevalence of cervical human papillomavirus infection and the most at-risk genotypes among Iranian healthy women: A systematic review and meta-analysis. Int J Prev Med, 7, 70.

Marlow LA, Waller J, Wardle J (2007). Public awareness that HPV is a risk factor for cervical cancer. Br J Cancer, 97, 691-4.

Martel C, Plummer M, Vignat J, Franceschi S (2017). Worldwide burden of cancer attributable to HPV by site, country and HPV type. Int J Cancer, 141, 664-70.

Medeiros R, Ramada D (2010). Knowledge differences between male and female university students about human papillomavirus (HPV) and cervical cancer: Implications for health strategies and vaccination. Vaccine, 29, 153-60.

Mojahed S, Karimi Zarchi M, Bokaie M, Salimi T (2013). Attitude and knowledge of Iranian female nurses about human papilomavirus infection and cervical cancer: a cross sectional survey. J Prev Med Public Health, 54, 187-90.

Naud PS, Roteli-Martins CM, De Carvalho NS, et al (2014). Sustained efficacy, immunogenicity, and safety of the HPV-16/18 AS04-adjuvanted vaccine: final analysis of a long-term follow-up study up to 9.4 years post-vaccination. Hum Vaccin Immunother, 10, 2147-62.

Nekooi M, Ayazi S, Gandomi M, Moosavi S Gh, Fakhri A (2016). Level of knowledge about human papillomavirus infection among women of Kashan city, Iran. IAHS, 3, 7-12.

pourkazemi A GA, Fakour F, Ghorbani S (2016). Knowledge and attitudes of medical students toward human papilloma virus in Rasht. $J$ Guilan Univ of Med Sci, 25, 1-10.

Salehifar D, Akbari Kamrani M (2015). Knowledge about cervical cancer, human papilloma virus and attitude towards acceptance of vaccination among female students. Payesh, 2, 217-26.

Slomovitz BM, Sun CC, Frumovitz M, et al (2006). Are women ready for the HPV vaccine. Gynecol Oncol, 103, 151-4.

Smith JS, Melendy A, Rana RK, Pimenta JM (2008). Age-specific prevalence of infection with human papillomavirus in females: a global review. J Adolesc Health, 43, 5-25.

World Health Organization (2017). Human papillomavirus Vaccines, WHO position paper, 92, pp 241-68.

\section{c) (7) (8)}

This work is licensed under a Creative Commons AttributionNon Commercial 4.0 International License. 